\title{
Pengaruh Kecerdasan Emosional, Fasilitas Belajar dan Kompetensi Dosen Terhadap Persepsi Prestasi Akademik Mahasiswa Akuntansi
}

\author{
Putu Hendra Putra Wahyudi ${ }^{1}$ \\ Fakultas Ekonomi dan Bisnis \\ Universitas Udayana, Indonesia. \\ Email: wahyudi.hendra49@yahoo.com
}

\author{
Maria Mediatrix Ratna Sari ${ }^{2}$ \\ Fakultas Ekonomi dan Bisnis \\ Universitas Udayana, Indonesia.
}

\begin{abstract}
ABSTRAK
Prestasi akademik mahasiswa merupakan sebuah cerminan kuantitas dan kualitas pengetahuan yang telah dikuasai oleh mahasiswa. Tujuan dari penelitian ini antara lain untuk mengetahui pengaruh, kecerdasan emosional, fasilitas belajar dan kompetensi dosen terhadap prestasi akademik mahasiswa akuntansi. Tempat dilakukannya penelitian ini adalah di Fakultas Ekonomi dan Bisnis Universitas Udayana. Analisis regresi linear berganda merupakan teknik analisis yang digunakan dalam penelitian ini. Sampel penelitian ini adalah mahasiswa S1 akuntansi angkatan 2016 dengan metode penentuan sampel menggunakan rumus Slovin. Jenis data yang digunakan dalam penelitian ini adalah data kualitatif dan kuantitatif. Teknik pengumpulan data menggunakan kuesioner. Hasil penelitian menunjukkan bahwa, kecerdasan emosional, fasilitas belajar dan kompetensi dosen berpengaruh positif terhadap prestasi akademik mahasiswa akuntansi.
\end{abstract}

Kata Kunci : Kecerdasan Emosional; Fasilitas Belajar; Kompetensi Dosen; Prestasi Akademik.

\section{The Effect Of Emotional Intelligence, Learning Facilities And Lecturer Competence On Perception of Accounting Students Academic Achievements}

\section{ABSTRACT}

Student academic achievement is a reflection of the quantity and quality of knowledge that has been mastered by students. The purpose of this study, among others, is to determine the effect, emotional intelligence, learning facilities and lecturer competence on the academic achievement of accounting students. The place to do this research is at the Faculty of Economics and Business, Udayana University. Multiple linear regression analysis is an analysis technique used in this study. The sample of this research is the 2016 accounting undergraduate students with the sample determination method using the Slovin formula. The types of data used in this study are qualitative and quantitative data. Data collection techniques using a questionnaire. The results showed that emotional intelligence, learning facilities and lecturer competence had a positive effect on academic achievement of accounting students.

Keywords: Emotional Intelligence; Learning Facilities; lecturer Competence; Academic Achievement.

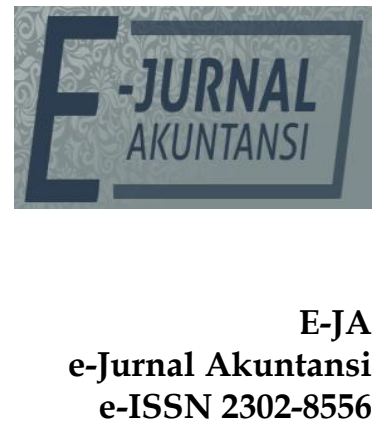

Vol. 29 No. 3

Denpasar, Desember 2019

Hal. 1083-1093

Artikel masuk: 12 September 2019

Tanggal diterima: 17 Desember 2019 


\section{PENDAHULUAN}

Perguruan tinggi memiliki peran penting sebagai salah satu tempat pendidikan formal yang mempunyai tugas dan tanggung jawab untuk mempersiapkan mahasiswa sesuai dengan sistem pendidikan nasional. Baik buruknya mutu pendidikan di perguruan tinggi dapat ditinjau dari input, proses, dan output yang dihasilkan. Input pendidikan dapat berupa input sumber daya manusia, input sumber daya non manusia dan juga input harapan-harapan. Input sumber daya manusia dalam perguruan tinggi mencakup tenaga pendidik (dosen), peserta didik (mahasiswa), dan juga seluruh karyawan. Input sumber daya non manusia dalam perguruan tinggi mencakup fasilitas-fasilitas penunjang kegiatan belajar. Sedangkan input harapan-harapan dalam perguruan tinggi berupa visi, misi, tujuan, dan sasaran-sasaran yang ingin dicapai oleh perguruan tinggi tersebut.

Proses merupakan rangkaian kegiatan yang membuat sesuatu berubah menjadi sesuatu yang lain, dalam hal ini yaitu mengubah input menjadi output. Salah satu contoh proses pembelajaran di perguruan tinggi dapat dilihat dari interaksi yang saling bersinergi antara dosen sebagai tenaga pendidik dengan mahasiswa sebagai peserta didik. Selain mahasiswa yang perlu lebih aktif dalam belajar, dosen juga perlu untuk menggunakan berbagai macam model, metode, dan strategi untuk mengelola dan menghasilkan kegiatan pembelajaran yang lebih bervariasi.

Output merupakan hasil dari input yang telah melalui rangkaian proses terlebih dahulu. Salah satu output pendidikan dalam perguruan tinggi adalah prestasi akademik yang dihasilkannya. Semakin tinggi tingkat kesiapan input dan semakin efektif rangkaian proses pendidikan maka output yang dihasilkan perguruan tinggi tersebut semakin baik.

Fenomena kualitas belajar di perguruan tinggi seringkali dipertanyakan dalam hal mencetak tenaga profesional yang mampu bersaing dalam dunia kerja, salah satunya adalah lulusan di bidang akuntansi. International Academic Institute for Science and Technology dalam hasil studinya menyatakan bahwa Indonesia hanya memiliki akuntan profesional sekitar 10.000 orang padahal tenaga akuntan profesional yang diperlukan di Indonesia diperkirakan mencapai angka 200.000 orang (wartaekonomi.co.id). Hal tersebut sekaligus membuat Indonesia menjadi negara di kawasan Asia Tenggara yang memiliki jumlah akuntan profesional paling sedikit. Ini menjadi sebuah ironi karena mahasiswa yang menempuh pendidikan akuntansi bisa terbilang sangat banyak di Indonesia.

Prestasi akademik juga biasa dikenal dengan prestasi belajar. Prestasi belajar dapat diartikan sebagai kecakapan nyata yang dapat diukur dengan pengetahuan, sikap, dan keterampilan sebagai interaksi aktif antara subyek belajar dengan obyek belajar selama berlangsungnya proses belajar mengajar untuk mencapai hasil belajar (Sunarsi, 2017). Pencapaian prestasi akademik dapat dipengaruhi oleh faktor internal dan faktor eksternal (Slameto, 2010:54). Faktor internal adalah faktor yang berasal dari dalam diri seorang individu seperti contohnya keadaan psikologis dan keadaan jasmani individu itu sendiri, sedangkan faktor eksternal adalah faktor yang berasal dari luar individu seperti kondisi kawasan atau zona di sekitar individu tersebut. Salah satu faktor internal yang berkaitan dengan prestasi akademik adalah kecerdasan emosional. Konsep kecerdasan emosional terdiri dari mengidentifikasi, menerapkan, memahami dan 
berurusan dengan emosi. Kecerdasan emosional juga penting untuk memiliki komunikasi dan keterampilan interpersonal yang lebih baik (Unnikrishnan et al., 2015). Mohzan, Hassan, \& Halil (2013) berpendapat bahwa jika seseorang memiliki kecerdasan emosional yang tinggi maka hal tersebut dapat memberikan keuntungan tambahan bagi individu itu sendiri, baik dalam mengejar pendidikan ataupun pengembangan karir.

Selain faktor internal berupa kecerdasan emosional, prestasi akademik mahasiswa juga bergantung pada faktor eksternal seperti fasilitas belajar dan kompetensi dosen. Keberadaan fasilitas belajar ini sangat berpengaruh dalam menunjang kegiatan pembelajaran. Lengkapnya fasilitas belajar yang tersedia dapat memengaruhi proses belajar mahasiswa untuk mencapai prestasi akademik yang lebih baik. Hal serupa juga tertuang dalam penelitian Putro, Sunarto, \& Sudarno (2017) yang menyatakan bahwa kelengkapan fasilitas belajar dapat membantu dalam belajar serta kurang lengkapnya alat-alat atau fasilitas pembelajaran dapat menghambat kemajuan belajar.

Faktor eksternal lain yang berkaitan dengan prestasi akademik mahasiswa akuntansi adalah kompetensi dosen. Berdasarkan undang-undang No 14 tahun 2005 pasal 69 ayat 2 "Kompetensi dosen meliputi kompetensi pedagogik, kompetensi kepribadian, kompetensi sosial, dan kompetensi profesional." Menurut Astuty (2015), ketika empat kompetensi dosen yang tertera di undangundang No 14 tahun 2005 pasal 69 ayat 2 diteliti secara terpisah, hanya kompetensi pedagogik yang berpangaruh signifikan terhadap prestasi akademik mahasiswa sedangkan kompetensi lainnya tidak memengaruhi peningkatan prestasi akademik mahasiswa. Dosen yang berkompeten sangat dibutuhkan dalam dunia pendidikan untuk memaksimalkan prestasi akademik yang nantinya dicapai oleh mahasiswa, maka dari itu setiap perguruan tinggi telah melakukan upaya untuk menghasilkan dosen yang berkompeten dengan cara menaikkan standar pendidikan dosen yang kini minilam strata-2.

Teori kognitif sosial (social cognitive theory) merupakan teori yang dikembangkan oleh Albert Bandura. Konsep utama dari teori kognitif sosial adalah pengertian tentang observational learning atau proses belajar dengan mengamati (Wood \& Bandura, 1989). Teori kogintif sosial memiliki asumsi bahwa manusia cukup adaptif dalam memelajari berbagai sikap maupun perilaku serta kemampuan tertentu melalui proses pembelajaran secara tidak langsung (pengalaman tidak langsung). Bandura (1999) menyatakan manusia merupakan sebuah sistem yang disebut sistem diri (self system). Hal tersebut berarti bahwa setiap faktor yang ada dalam diri suatu individu dan segala jenis peristiwa yang terjadi di ruang lingkup individu tersebut saling terkait sebagai penentu atau penyebab yang satu terhadap yang lainnya. Selain itu, teori ini juga menunjukkan bahwa antara perilaku individu, lingkungan dan juga persepsi memiliki peran penting dalam proses pembelajaran sosial. Komponenkomponen tersebut saling berhubungan satu sama lainnya, sehingga proses pembelajaran sosial tidak akan tercipta jika komponen-komponen tersebut tidak saling bereaksi.

Menurut Goleman (2003:45) kecerdasan emosional adalah kemampuan diri untuk memotivasi diri sendiri, mengendalikan dorongan hati, mengatur suasana hati serta berempati dan berdoa. Menurut penelitian Putro et al. (2017), 
kecerdasan emosional memiliki pengaruh positif dan signifikan secara parsial serta secara simultan terhadap prestasi akademik mahasiswa. Akbarilakeh, Naderi, \& Arbabisarjou (2018) dalam penelitiannya menyatakan bahwa adanya hubungan positif yang signifikan antara kecerdasan emosional dengan kesuksesan akademik. Selain itu, hasil penelitian I Cenik, Lerbin, \& Elizabeth (2013) juga menyatakan bahwa variabel kecerdasan emosional memiliki arah hubungan positif dengan prestasi akademik mahasiswa. Hipotesis yang dapat dirumuskan berdasarkan uraian di atas yaitu:

$\mathrm{H}_{1}$ : Kecerdasan emosional berpengaruh positif terhadap persepsi prestasi akademik mahasiswa akuntansi.

Menurut Aunurrahman (2010:85) fasilitas pendidikan meliputi sarana dan prasarana. Sarana yaitu semua peralatan serta kelengkapan yang langsung digunakan dalam proses pembelajaran sedangkan prasarana pembelajaran meliputi semua komponen yang langsung menunjang jalannya proses pembelajaran. Mushtaq \& Khan (2012) dalam hasil penelitiannya menyatakan bahwa adanya hubungan positif antara fasilitas belajar dengan performa belajar mahasiswa. Uline \& Tschannen-Moran (2008) dalam penelitiannya mendapatkan hasil bahwa kualitas fasilitas berpengaruh positif terhadap prestasi siswa matematika dan bahasa inggris. Hal tersebut juga dinyatakan oleh Ramli \& Zain (2018) yang dalam penelitiannya mendapatkan hasil bahwa infrastuktur dan lingkungan belajar berpengaruh positif terhadap prestasi akademik mahasiswa. Selain itu menurut Weerasinghe \& Fernando (2018) fasilitas ruang dosen, fasilitas perpustakaan, fasilitas komputer, fasilitas akomodasi, fasilitas pegawai dan juga fasilitas hiburan berpengaruh positif terhadap kepuasan mahasiswa. Hipotesis yang dapat dirumuskan berdasarkan uraian di atas yaitu:

$\mathrm{H}_{2}$ : Fasilitas belajar berpengaruh positif terhadap persepsi prestasi akademik mahasiswa akuntansi.

Berdasarkan UU No. 13/2003 pasal 1 ayat 10 tentang ketenagakerjaan, pengertian kompetensi adalah kemampuan kerja setiap individu yang mencakup aspek pengetahuan, keterampilan dan sikap kerja yang sesuai dengan standar yang ditetapkan. Berdasarkan hal tersebut, maka dapat dikatakan bahwa kompetensi dosen merupakan gabungan dari kompetensi individu yang diaktualisasikan secara kualitas maupun kuantitas dalam suatu kinerja. Berdasarkan UU No. 14 tahun 2005 pasal 69 ayat 2, kompetensi dosen meliputi kompetensi pedagogik, kompetensi kepribadian, kompetensi sosial, dan kompetensi professional. Berdasarkan penelitian Muzenda (2013), kompetensi dosen berpengaruh positif terhadap kinerja akademik mahasiswa. Hasil penelitian Mediawati (2010) menyatakan bahwa kompetensi dosen memiliki pengaruh positif dan signifikan baik secara parsial maupun simultan terhadap prestasi belajar mahasiswa. Menurut Hakim (2015), kompetensi dosen berpengaruh positif terhadap performa belajar. Selain itu, Long, Ibrahim, \& Kowang (2014) dalam penelitiannya memperoleh hasil bahwa kompetensi dosen berpengaruh positif terhadap kepuasan mahasiswa. Hipotesis yang dapat dirumuskan berdasarkan uraian di atas yaitu:

$\mathrm{H}_{3}$ : Kompetensi dosen berpengaruh positif terhadap persepsi prestasi akademik mahasiswa akuntansi. 


\section{METODE PENELITIAN}

Berdasarkan permasalahan yang diteliti, penelitian ini digolongkan pada penelitian kuantitaif asosiatif (hubungan) dengan tipe kausalitas. Tempat penelitian ini dilakukan yaitu di Fakultas Ekonomi dan Bisnis Universitas Udayana. Obyek penelitian ini merupakan pengaruh kecerdasan emosional, fasilitas belajar dan kompetensi dosen terhadap persepsi prestasi akademik mahasiswa akuntansi.

Regresi linear berganda merupakan teknik analisis yang dipakai dalam penelitian ini. Populasi penelitian ini antara lain adalah seluruh mahasiswa S1 akuntansi di Fakultas Ekonomi dan Bisnis Universitas Udayana. Teknik pengambilan sampel yang digunakan dalam penelitian ini adalah purposive sampling dengan kriterianya adalah mahasiswa angkatan 2016 yang kini menginjak semester 7 dan masih aktif kuliah. Alasan penggunaan kriteria tersebut karena mahasiswa selama 7 semester telah menempuh semua mata kuliah program studi Akuntansi di Fakultas Ekonomi Dan Bisnis Universitas Udayana sehingga prestasi akademik yang telah dihasilkan dianggap mampu memberikan representasi mengenai hasil belajar selama menempuh kuliah. Jumlah sampel yang didapat adalah sebanyak 77 orang dengan cara menggunakan rumus Slovin dalam metode penentuan sampelnya. Teknik pengumpulan data dalam penelitian ini adalah kuesioner. Feedback dari responden diukur menggunakan modifikasi skala likert empat poin. Menurut Hadi (1991:19), modifikasi terhadap skala likert dimaksudkan untuk menghilangkan kelemahan yang terkandung oleh skala lima tingkat dengan meniadakan kategori jawaban yang berada di tengah dengan 2 alasan. Pertama, menghilangkan jawaban ditengah-tengah karena jawaban ditengah-tengah tersmasuk kategori undeciden yang memiliki sifat multi interpretable yaitu jawaban yang mempunyai arti ganda. Kedua, meniadakan jawaban ditengah-tengah karena dengan tersedianya jawaban di tengah-tengah menyebabkan responden cenderung memilih jawaban ke tengah (central tendency effect), terutama bagi mereka yang ragu-ragu dalam menentukan pendapatnya ke arah setuju atau ke arah tidak setuju. Jika disediakan kategori jawaban di tengah tersebut maka informasi yang dapat dijaring dari responden cenderung kurang maksimal.

\section{HASIL DAN PEMBAHASAN}

Hasil uji validitas menunjukkan nilai Pearson Correlation tiap instrumen penelitian yang digunakan untuk mengukur setiap variabel yaitu kecerdasan emosional, fasilitas belajar, kompetensi dosen dan persepsi prestasi akademik mahasiswa akuntansi telah di atas 0,3. Hal tersebut berarti bahwa setiap instrumen dalam penelitian ini dinyatakan telah valid.

Hasil uji reliabilitas menunjukkan bahwa semua variabel penelitian yang digunakan dalam penelitian ini reliabel untuk digunakan karena memiliki nilai Cronbach's Alpha yang melebihi 0,6. 
Tabel 1. Hasil Uji Reliabilitas

\begin{tabular}{llcl}
\hline No & Variabel & Cronbach's Alpha & Keterangan \\
\hline 1 & Kecerdasan Emosional $\left(\mathrm{X}_{1}\right)$ & 0,921 & Reliabel \\
2 & Fasilitas Belajar $\left(\mathrm{X}_{2}\right)$ & 0,869 & Reliabel \\
3 & Kompetensi Dosen $\left(\mathrm{X}_{3}\right)$ & 0,910 & Reliabel \\
4 & Persepsi Prestasi Akademik & 0,921 & Reliabel \\
& Mahasiswa Akuntansi $(\mathrm{Y})$ & & \\
\hline
\end{tabular}

Sumber: Data Penelitian, 2019

Hasil uji analisis statistik deskriptif menunjukkan bahwa variabel kecerdasan emosional $\left(\mathrm{X}_{1}\right)$ menghasilkan nilai min sebesar 59 dan nilai max sebesar 84. Variabel kecerdasan emosional juga menghasilkan nilai mean sebesar 67,5974 dengan nilai standar deviasinya sebesar 6,39338. Variabel fasilitas belajar $\left(\mathrm{X}_{2}\right)$ mnghasilkan nilai min sebesar 37 dan nilai max sebesar 52. Variabel fasilitas belajar juga menghasilkan nilai mean sebesar 42,1429 dengan nilai standar deviasinya sebesar 3,86521. Variabel kompetensi dosen $\left(X_{3}\right)$ menghasilkan nilai min sebesar 60 dan nilai max sebesar 80. Variabel kompetensi dosen juga menghasilkan nilai mean sebesar 64,8312 dengan nilai standar deviasinya sebesar 6,60224. Selanjutnya, persepsi prestasi akademik mahasiswa akuntansi (Y) menghasilkan nilai min sebesar 23 dan nilai max sebesar 32. Variabel persepsi prestasi akademik mahasiswa akuntansi juga menghasilkan nilai mean sebesar 25,8182 dengan nilai standar deviasinya sebesar 2,56355.

Tabel 2. Hasil Statistik Deskriptif

\begin{tabular}{|c|c|c|c|c|c|}
\hline Variabel & $\mathrm{N}$ & Min. & Max. & Mean & $\begin{array}{c}\text { Std. } \\
\text { Deviasi }\end{array}$ \\
\hline $\begin{array}{l}\text { Kecerdasan } \\
\text { Emosional }\left(\mathrm{X}_{1}\right)\end{array}$ & 7 & 59 & 84 & 67,5974 & 6,39338 \\
\hline $\begin{array}{l}\text { Fasilitas Belajar } \\
\left(\mathrm{X}_{2}\right)\end{array}$ & 7 & 37 & 52 & 42,1429 & 3,86521 \\
\hline $\begin{array}{l}\text { Kompetensi } \\
\text { Dosen }\left(X_{3}\right)\end{array}$ & 7 & 60 & 80 & 64,8312 & 6,60224 \\
\hline $\begin{array}{l}\text { Persepsi Prestasi } \\
\text { Akademik } \\
\text { Mahasiswa } \\
\text { Akuntansi }(\mathrm{Y})\end{array}$ & 7 & 23 & 32 & 25,8182 & 2,56355 \\
\hline \multirow{2}{*}{\multicolumn{6}{|c|}{$\begin{array}{l}\text { Sumber: Data Penelitian, } 2019 \\
\text { Nilai signifikansi yang dihasilkan setelah melakukan uji normalitas adalah } \\
\text { 0,90. Hal ini berarti model persamaan regresi pada penelitian ini berdistribusi } \\
\text { normal karena nilai signifikansi uji Kolmogorov-Smirnov yang dihasilkan telah } \\
\text { melebihi nilai yang ditentukan yaitu sebesar } 0,05 \text {. } \\
\text { Tabel 3. Hasil Uji Normalitas (One-Sample Kolmogorov-Smirnov Test) } \\
\text { Unstandardized Residual }\end{array}$}} \\
\hline & & & & & \\
\hline $\begin{array}{l}\mathrm{N} \\
\text { Kolmogorov- } \\
\text { Asymp. Sig. }\end{array}$ & $\begin{array}{l}\text { ov Z } \\
\text { d) }\end{array}$ & & $\begin{array}{l}77 \\
1,246 \\
0,090\end{array}$ & & \\
\hline
\end{tabular}

Sumber: Data Penelitian, 2019

Seluruh variabel bebas dalam penelitian ini yaitu kecerdasan emosional, fasilitas belajar dan juga kompetensi dosen dinyatakan bebas dari multikolinearitas. Hal tersebut dapat dilihat dari hasil uji multikolinearitas yang 
menunjukkan bahwa nilai tolerance yang dihasilkan masing-masing variabel bebas melebihi 10\% dan nilai VIF yang dihasilkan masing-masing variabel bebas lebih kecil dari 10.

Tabel 4. Hasil Uji Multikolinieritas

\begin{tabular}{|c|c|c|c|}
\hline Variabel & Tolerance & VIF & Keterangan \\
\hline Kecerdasan & 0,373 & 2,682 & Bebas Multikol \\
\hline Emosional $\left(X_{1}\right)$ & & & \\
\hline Fasilitas Belajar $\left(\mathrm{X}_{2}\right)$ & 0,325 & 3,075 & Bebas Multikol \\
\hline $\begin{array}{l}\text { Kompetensi Dosen } \\
\left(\mathrm{X}_{3}\right)\end{array}$ & 0,283 & 3,532 & Bebas Multikol \\
\hline
\end{tabular}

Sumber: Data Penelitian, 2019

Pada hasil uji heteroskedastisitas dapat dilihat bahwa nilai signifikansi dari kecerdasan emosional sebesar 0,382, fasilitas belajar sebesar 0,310, dan kompetensi dosen sebesar 0,224. Hal tersebut menunjukkan bahwa keseluruhan variabel bebas tidak mengandung gejala heteroskedastisitas karena nilai signifikansi yang dihasilkan telah melebihi jumlah nilai yang ditentukan yaitu 0,05 .

Tabel 5. Hasil Uji Heteroskedastisitas

\begin{tabular}{lll}
\hline \multicolumn{1}{c}{ Variabel } & Signifikansi & Keterangan \\
\hline Kecerdasan Emosional $\left(\mathrm{X}_{1}\right)$ & 0,382 & Bebas Heteroskedastisitas \\
Fasilitas Belajar $\left(\mathrm{X}_{2}\right)$ & 0,310 & Bebas Heteroskedastisitas \\
Kompetensi Dosen $\left(\mathrm{X}_{3}\right)$ & 0,224 & Bebas Heteroskedastisitas \\
\hline
\end{tabular}

Sumber: Data Penelitian, 2019

Persamaan regresi yang dapat dibuat berdasarkan hasil uji analisis regresi linear berganda tersebut adalah sebagai berikut:

$$
Y=0,288+0,081 X_{1}+0,263 X_{2}+0,138 X_{3}
$$

Nilai konstanta $(\alpha)$ sebesar 0,288 memiliki arti bahwa variabel prestasi akademik mahasiswa akuntansi cenderung positif jika variabel kecerdasan emosional, fasilitas belajar dan kompetensi dosen dinyatakan konstan pada angka 0. Nilai 0,081 merupakan nilai koefisien regresi $\beta_{1}$ untuk variabel kecerdasan emosional yang berarti bahwa peningkatan variabel kecerdasan emosional juga akan menyebabkan peningkatan pada variabel persepsi prestasi akademik mahasiswa akuntansi, dengan dugaan variabel independen yang lain tidak mengalami perubahan. Nilai 0,263 merupakan nilai koefisien regresi $\beta_{2}$ untuk variabel fasilitas belajar yang berarti bahwa peningkatan variabel fasilitas belajar juga akan menyebabkan peningkatan pada variabel persepsi prestasi akademik mahasiswa akuntansi, dengan dugaan variabel independen yang lain tidak mengalami perubahan. Nilai 0,138 merupakan nilai koefisien regresi $\beta_{3}$ untuk variabel kompetensi dosen yang berarti bahwa peningkatan variabel kompetensi dosen juga akan menyebabkan peningkatan pada variabel persepsi prestasi akademik mahasiswa akuntansi, dengan dugaan variabel independen yang lain tidak mengalami perubahan.

Setelah melakukan uji $\mathrm{F}$ maka dapat dilihat nilai $\mathrm{F}$ hitung yang di dapat adalah sebesar 86,006 dengan nilai signifkansi sebesar 0,000. Hasil ini mempunyai arti bahwa ada pengaruh signifikan antara kecerdasan emosional, fasilitas belajar dan kompetensi dosen terhadap persepsi prestasi akademik 
mahasiswa akuntansi karena nilai signifikansi yang dihasilkan lebih kecil dibanding 0,05.

Hasil analisis uji koefisien determinasi menunjukkan bahwa nilai Adjusted $\mathrm{R}^{2}$ sebesar 0,770 . Hal ini berarti perubahan yang terjadi pada persepsi prestasi akademik mahasiswa akuntansi dapat dijelasakan oleh kecerdasan emosional, fasilitas belajar dan kompetensi dosen sebesar 77\% sedangkan sisanya dijelaskan oleh faktor laain yang tidak diuji dalam penelitian ini.

Berdasarkan hasil uji hipotesis pengaruh kecerdasan emosional terhadap persepsi prestasi akademik mahasiswa akuntansi diperoleh nilai signifikasi sebesar 0,028 dengan nilai koefisien regresi positif sebesar 0,081. Hasil ini mempunyai arti bahwa kecerdasan emosional berpengaruh positif terhadap persepsi prestasi akademik mahasiswa akuntansi. Hasil penelitian ini mendukung hipotesis pertama yang menyatakan bahwa terdapat pengaruh kecerdasan emosional terhadap persepsi prestasi akademik mahasiswa akuntansi. Hasil penelitian ini mendukung hasil penelitian yang dilakukan oleh Costa \& Faria (2015), Andiri, Jajat, \& Sultoni (2017), dan Akbarilakeh et al. (2018) yang membuktikan bahwa kecerdasan emosional berpengaruh positif terhadap prestasi akademik. Selain itu, hasil penelitian ini didukung oleh teori kognitif sosial yang menyatakan bahwa manusia cenderung fleksibel dan mampu mempelajari berbagai sikap maupun perilaku serta kemampuan tertentu melalui proses pembelajaran secara tidak langsung (pengalaman tidak langsung). Kemampuan manusia dalam mempelajari sikap atau perilaku berdasarkan metode observasi memerlukan kecerdasan emosional yang dominan. Kemampuan kecerdasan emosional dalam memahami, merasakan lalu mengontrol emosi sehingga dapat menjadi sumber energi, informasi dan koneksi dapat menjadi dasar bagi mahasiswa untuk meningkatkan kualitas prestasi akademiknya dengan cara lebih mengenal siapa dirinya, dapat memotivasi diri sendiri, lebih dapat mengendalikan diri, lebih terampil dalam bersosialisasi, dan lebih berempati pada lingkungan sekitarnya.

Berdasarkan hasil uji hipotesis pengaruh fasilitas belajar terhadap persepsi prestasi akademik mahasiswa akuntansi diperoleh nilai signifikasi sebesar 0,000 dengan nilai koefisien regresi positif sebesar 0,263. Hasil ini mempunyai arti bahwa fasilitas belajar berpengaruh positif terhadap persepsi prestasi akademik mahasiswa akuntansi. Hasil penelitian ini mendukung hasil penelitian yang dilakukan oleh Uline \& Tschannen-Moran (2008), Akomolafe \& Adesua (2016), serta Ramli \& Zain (2018) yang membuktikan bahwa fasilitas belajar berpengaruh positif terhadap prestasi akademik. Selain itu, hasil penelitian ini juga didukung oleh teori kognitif sosial yang menyatakan bahwa proses pembelajaran sosial cenderung terjadi akibat aksi reaksi dari individu, lingkungan, dan persepsi. Pemanfaatan fasilitas belajar yang nantinya akan memengaruhi prestasi yang dihasilkan adalah salah satu contoh proses pembelajaran sosial yang didasari dari aksi reaksi antaran individu dengan lingkungannya.

Berdasarkan hasil uji hipotesis pengaruh kompetensi dosen terhadap persepsi prestasi akademik mahasiswa akuntansi diperoleh nilai signifikasi sebesar 0,001 dengan nilai koefisien regresi positif sebesar 0,138. Hasil ini mempunyai arti bahwa kompetensi dosen berpengaruh positif terhadap persepsi 
prestasi akademik mahasiswa akuntansi. Hasil penelitian ini mendukung hasil penelitian yang dilakukan oleh Mediawati (2010), Muzenda (2013) dan Hakim (2015) yang membuktikan bahwa kompetensi dosen berpengaruh positif terhadap prestasi akademik. Selain itu, hasil penelitian ini juga didukung oleh teori kognitif sosial yang menyatakan bahwa setiap individu cenderung belajar dengan cara mengobservasi atau mengamati. Kemampuan belajar dengan cara mengobservasi memungkinkan subyek untuk memahami dan mengingat apa yang dilihat, melakukan identifikasi dan meniru perilaku. Mahasiswa cenderung mengamati atau mengobservasi perilaku dan metode pembelajaran yang diberikan dosen, sehingga apabila dosen memiliki kompetensi yang baik maka hal tersebut dapat berdampak pada prestasi akademik yang dihasilkan mahasiswa.

Tabel 6. Hasil Analisis Regresi Linier Berganda

\begin{tabular}{lllll}
\hline Model & & $\begin{array}{l}\text { Koefisien } \\
\text { Regresi }\end{array}$ & $\begin{array}{l}\text { Std. } \\
\text { Error }\end{array}$ & Sig. \\
\hline 1 & (Constant) & 0,288 & 1,634 & 0,861 \\
& Kec. Emosional & 0,081 & 0,036 & 0,028 \\
& Fasilitas Belajar & 0,263 & 0,064 & 0,000 \\
& Kom. Dosen & 0,138 & 0,040 & 0,001 \\
& R Square & 0,779 & & \\
& Adjusted R Square & 0,770 & & \\
& F hitung & 86,006 & & \\
& Signifikansi F & 0,000 & & \\
& &
\end{tabular}

Sumber: Data Penelitian, 2019

Hasil penelitian ini diharapkan memberikan implikasi bagi para pembaca, khususnya mahasiswa, dosen dan seluruh elemen dalam perguruan tinggi, sebagai bahan pertimbangan agar nantinya dapat berbenah ke arah yang lebih baik sehingga dapat meningkatkan kualitas output pendidikan yang dihasilkan, terutama dalam hal menghasilkan lulusan-lulusan di bidang akuntansi yang profesional dan dapat bersaing di dunia kerja.

\section{SIMPULAN}

Simpulan yang dapat ditarik berdasarkan hasil penelitian ini antara lain kecerdasan emosional berpengaruh positif terhadap persepsi prestasi akademik mahasiswa akuntansi, fasilitas belajar berpengaruh positif terhadap persepsi prestasi akademik mahasiswa akuntansi dan kompetensi dosen berpengaruh positif terhadap persepsi prestasi akademik mahasiswa akuntansi.

Penelitian ini tidak luput dari kekurangan maupun keterbatasan. Salah satu kekurangan penelitian ini adalah peneliti hanya meneliti satu perguruan tinggi. Untuk itu diharapkan peneliti selanjutnya dapat memperlebar cakupan penelitian dengan mengambil sampel mahasiswa akuntansi dari berbagai perguruan tinggi lain baik swasta maupun negeri. Selain itu, peneliti berikutnya juga disarankan untuk menambah faktor-faktor lain yang mungkin dapat menghambat prestasi akademik misalnya, apakah mahasiswa tersebut sudah bekerja atau sudah berkeluarga. 


\section{REFERENSI}

Akbarilakeh, M., Naderi, A., \& Arbabisarjou, A. (2018). Critical Thinking and Emotional Intelligence Skills and Relationship with Students' Academic Achievement. La Prensa Medica Argentina, 104(2), 1-5. https://doi.org/10.4172/0032-745X.1000280

Akomolafe, C. O., \& Adesua, V. O. (2016). The Impact of Physical Facilities on Students' Level of Motivation and Academic Performance in Senior Secondary Schools in South. Journal of Education and Practice, 7(4), 38-42.

Andiri, L., Jajat, \& Sultoni, K. (2017). Hubungan Kecerdasan Emosi dengan Prestasi Akademik Mahasiswa Olahraga. Jurnal Terapan Ilmu Keolahragaan, 2(2), 137-141. https:// doi.org/10.17509/jtikor.v2i2.8063

Astuty, E. (2015). Implementation Analysis of Lecturer's Pedagogical Competence on Student's Academic Achievement. Journal of Management Research, 7(2), 152-168. https://doi.org/10.5296/jmr.v7i2.6834

Bandura, A. (1999). Social Cognitive Theory of Personality: Theory and research. Handbook of Personality, 154-196. https://doi.org/10.1016/07495978(91)90022-L

Costa, A., \& Faria, L. (2015). The Impact of Emotional Intelligence on Academic Achievement: A Longitudinal Study in Portuguese Secondary School. Learning and Individual Differences, 37(1), 38-47. https://doi.org/10.1016/j.lindif.2014.11.011

Hakim, A. (2015). Contribution of Competence Teacher (Pedagogical, Personality, Professional Competence and Social) On the Performance of Learning. The International Journal Of Engineering And Science, 4(2), 1-12. Retrieved from www.theijes.com

I Cenik, A., Lerbin, R. A., \& Elizabeth, S. D. (2013). Kecerdasan Intelektual, Kecerdasan Emosional, Kecerdasan Spiritual dan kesihatan Fisik untuk Memprediksi Prestasi Belajar Mahasiswa Akuntasi. Jurnal Akuntansi, 17(03), 444-458.

Long, C. S., Ibrahim, Z., \& Kowang, T. O. (2014). An Analysis on the Relationship Between Lecturers Competencies and Students Satisfaction. International Education Studies, 7(1), 37-46. https://doi.org/10.5539/ies.v7n1p37

Mediawati, E. (2010). Pengaruh Motivasi Belajar Mahasiswa Dan Kompetensi Dosen Terhadap Prestasi Belajar. Jurnal Pendidikan Ekonomi Dinamika Pendidikan, 5(2), 134-146. https://doi.org/10.15294/dp.v5i2.4922

Mohzan, M. A. M., Hassan, N., \& Halil, N. A. (2013). The Influence of Emotional Intelligence on Academic Achievement. Procedia Social and Behavioral Sciences, 90, 303-312. https:// doi.org/10.1016/j.sbspro.2013.07.095

Mushtaq, I., \& Khan, S. N. (2012). Factors Affecting Student's Academic Performance. Global Journal of Management and Bussiness Research, 12(9), 1622. https:/ / doi.org/10.1002/ tea.3660200906

Muzenda, A. (2013). Lecturer s ' Competences and Students ' Academic Performance. International Journal of Humanities and Social Science Invention, 3(1), 6-13.

Putro, S. A., Sunarto, \& Sudarno. (2017). Pengaruh Kecerdasan Emosional (EQ) Dan Fasilitas Pembelajaran Terhadap Prestasi Akademik Mahasiswa Pendidikan Ekonomi UNS. Jurnal Pendidikan Bisnis Dan Ekonomi, 3(2), 1-12. 
Ramli, A., \& Zain, M. R. (2018). The Impact of Facilities on Student's Academic Achievement. The Science International (Lahore), 30(2), 299-311. Retrieved from http:/ / www.sci-int.com/pdf/636613109483179335.edited.pdf

Sunarsi, D. (2017). Pengaruh Disiplin, Motivasi, Dan Kompetensi Terhadap Prestasi Belajar. J. Mandiri, 1(2), 208-226.

Uline, C., \& Tschannen-Moran, M. (2008). The walls speak: The interplay of quality facilities, school climate, and student achievement. Journal of Educational Administration, 46(1), 55-73. https://doi.org/10.1108/09578230810849817

Unnikrishnan, B., Darshan, B., Kulkarni, V., Thapar, R., Mithra, P., Kumar, N., ... Najiza, H. (2015). Association of Emotional Intelligence with Academic Performance Among Medical Students in South India. Asian Journal of Pharmaceutical and Clinical Research, 8(2), 300-302.

Weerasinghe, I. M. S., \& Fernando, R. L. S. (2018). University Facilities and Student Satisfaction in Sri Lanka. International Journal of Educational Management, 32(5), 866-880. https:/ / doi.org/10.1108/IJEM-07-2017-0174

Wood, R., \& Bandura, A. (1989). Social Cognitive Theory of Organizational Management University of New South Wales. 14(3), 361-384. 